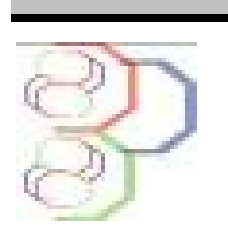

Journal of Applied Biosciences 106:10274 -10278

ISSN 1997-5902

\title{
Grafting compatibility between selected rootstocks and Tanzanian local tomato cultivars
}

\author{
Theodosy J. Msogoya*1 and Delphina Mamiro ${ }^{1}$ \\ ${ }^{1}$ Sokoine University of Agriculture, P.O Box 3005 Morogoro, Tanzania \\ *Corresponding author: tjmsogoya@yahoo.com
}

Original submitted in on $18^{\text {th }}$ July 2016. Published online at www.m.elewa.org on $31^{\text {st }}$ October 2016 http://dx.doi.org/10.4314/jab.v106i1.7

\begin{abstract}
Objective: The objective of this study was to evaluate the effect of different rootstocks on graft success of Tanzanian local tomato cultivars. Eggplant rootstocks (EG190, EG195, EG203 and EG219, and tomato rootstock (Hawaii 7996) were obtained from AVRDC in Taiwan while local tomato cultivars (Tengeru 97, Tanya, Cal-J and Riogrande) were sourced locally.

Methodology and Results: Cleft graft method was carried out when seedlings of eggplant, Hawaii 7996 and local tomato cultivars were 30,17 and 14 days old, respectively. The grafted seedlings with graft union tied using grafting clips were healed in a dark chamber for three days and then in a transparent chamber for three days. The average temperature and relative humidity in both chambers were maintained at $21-30^{\circ} \mathrm{C}$ and $85-95$ $\%$, respectively. The grafted seedlings were hardened for seven days in an open nursery with $30 \%$ overhead shade prior to transplanting. Data on graft success were subjected to analysis of variance using MSTATC statistical software and treatments mean separation was conducted based on Student-Newman Keuls at $P<5$ $\%$. Results show that graft success between eggplant rootstocks and local tomato cultivars was higher ranging from 86 to $100 \%$. On the contrary, grafting rootstock Hawaii 7996 with local tomato cultivars significantly (PS $5 \%$ ) resulted in a lower graft success ranging from 30 to $50 \%$ during the hardening stage in the open nursery. Conclusion and application of results: Tanzanian local tomato varieties can be grafted onto eggplant rootstocks EG190, EG195, EG203 and EG219 with high graft success. As these eggplant rootstocks are resistant to soil borne diseases, farmers should graft their varieties in order to increase tomato yield. Further studies are therefore required to optimize the grafting conditions to improve graft success between rootstock Hawaii 7996 and local tomato cultivars.
\end{abstract}

Key words: Grafting, Rootstocks, Local varieties, Tomato, Tanzania

\section{INTRODUCTION}

Grafting of commercial tomato cultivars on diseaseresistant plant cultivars has proved to be effective approach against disease control (King et al., 2008; Lee et al., 2010; Louws et al., 2010). For example, tomato rootstock cv. 'Hawaii 7996' is resistant against bacterial wilt and fusarium wilt diseases (Black et al., 2003). Similarly, some eggplant rootstocks such as 'EG190', 'EG195' and 'EG203' are reported to be resistant against flood damage, bacterial wilt, fusarium wilt, root-knot nematode and southern blight diseases (Nichols, 2007). Grafting tomato cultivars on vigorous rootstocks also enhances plant growth vigour, increases yield and promotes plant tolerance against environmental 
stresses (Rivard and Louws, 2006). Graft failures exhibited by some tomato scion and rootstock combinations are major challenge for a wider dissemination of tomato grafting technology (Fernandez-Garcia et al., 2004; Rodriquez and Bosland, 2010). Graft incompatibility is caused by low hydraulic conductance at the union, which reduces water and nutrient transport to the scions (Oda at el., 2005). Several factors are responsible for low hydraulic conductance including small root systems of rootstocks and limited formation or blockage of trans-union xylem connections at the

\section{MATERIALS AND METHODS}

Eggplant rootstocks (EG190, EG195, EG203 and EG219) and tomato rootstock (Hawaii 7996) were obtained from AVRDC in Taiwan while local commercial tomato cultivars (Tengeru 97, Tanya, Cal-J and Riogrande) were sourced locally. Rootstock and scion seeds were sown in $6 \mathrm{~cm}$ diameter pots at Sokoine University of Agriculture and grafting was conducted when eggplant, Hawaii 7996 and tomato cultivar seedlings were 30,17 and 14 days from the date of sowing, respectively. Grafting was carried out using cleft grafting method and the grafted union was tied

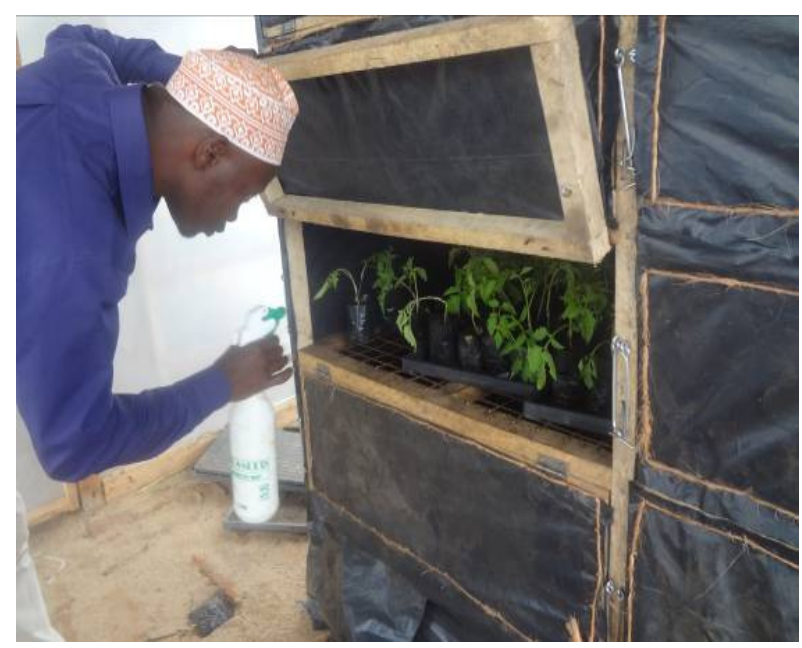

graft union (Parkinson et al., 1987). In Tanzania, grafting technology has the potential to overcome soil-borne diseases, which pose serious tomato yield losses. However, there are limited reports on grafting success between local tomato cultivars and selected eggplant and tomato rootstocks. The objective of this study was to assess the graft success between Tanzanian tomato cultivars and selected eggplant and tomato rootstocks imported from Asian Vegetables Research and Development Centre (AVRDC), Taiwan.

using grafting clip (Rivard and Louws, 2006). The grafted seedlings were healed in a dark chamber for 3-4 days and in a transparent chamber for 3-4 days (Figure 1). The temperature and relative humidity in the dark and transparent chambers were maintained at $85-95 \%$ and of $21-30^{\circ} \mathrm{C}$, respectively. The grafted seedlings were sprayed with water using a hand sprayer whenever wilting signs appeared. Neither fertilizer nor water was applied to the grafted seedlings during the healing process.

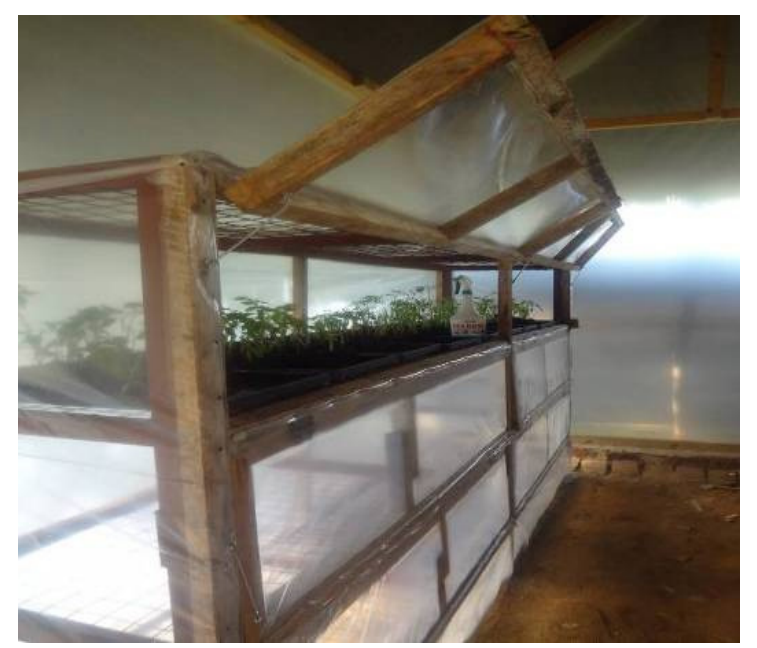

Figure 1: Grafted tomato seedlings in a dark and transparent healing chambers, respectively

The grafted seedlings were hardened for seven days in an open nursery with $30 \%$ overhead shade, ambient temperature of $25-29^{\circ} \mathrm{C}$ and relative humidity of $60-85 \%$ prior to transplanting in the field. Data on graft success were collected in each healing stage based on the number of survived seedlings. The data were subjected to analysis of variance using MSTATC statistical software and treatments mean separation was performed based on Student-Newman Keuls at $\mathrm{P}<5 \%$. 


\section{RESULTS AND DISCUSSION}

Results show that grafting local tomato cultivars on eggplant rootstocks and tomato rootstock genotype Hawaii 7996 significantly $(P \leq 5 \%)$ results in similar graft success in both the dark and transparent healing chambers (Table 1). The graft success in the dark healing chamber ranged from 92.5 to $100 \%$ while that in the transparent healing chamber ranged from 78.2 to $100 \%$.

Table 1: Effect to rootstocks on grafting success of Tanzanian local tomato cultivars

\begin{tabular}{|c|c|c|}
\hline \multirow[t]{2}{*}{ Rootstock-scion combination } & \multicolumn{2}{|c|}{ Graft success (\%) } \\
\hline & Dark healing chamber & $\begin{array}{c}\text { Transparent healing } \\
\text { chamber }\end{array}$ \\
\hline EG203/Tanya & $95.3 \pm 2.2 a$ & $96.8 \pm 4.6 a b$ \\
\hline EG190/Tanya & $100.0 \pm 0.0 a$ & $97.9 \pm 3.6 \mathrm{ab}$ \\
\hline EG190/Cal-J & $100.0 \pm 0.0 a$ & $97.9 \pm 3.6 a b$ \\
\hline EG190/Riogrande & $90.5 \pm 3.1 \mathrm{a}$ & $96.3 \pm 3.7 a b$ \\
\hline EG190/Tengeru97 & $92.5 \pm 11.3 a$ & $93.5 \pm 8.5 a b$ \\
\hline EG195/Tanya & $93.6 \pm 6.6 a$ & $100.0 \pm 0.0 a$ \\
\hline EG195/Cal-J & $100.0 \pm 0.0 a$ & $96.9 \pm 3.1 \mathrm{ab}$ \\
\hline EG195/Riogrande & $100.0 \pm 0.0 a$ & $100.0 \pm 0.0 a$ \\
\hline EG195/Tengeru97 & $100.0 \pm 0.0 \mathrm{a}$ & $100.0 \pm 0.0 \mathrm{a}$ \\
\hline EG203/Cal-J & $100.0 \pm 0.0 \mathrm{a}$ & $96.9 \pm 4.4 a b$ \\
\hline EG203/Riogrande & $100.0 \pm 0.0 \mathrm{a}$ & $90.6 \pm 8.8 \mathrm{ab}$ \\
\hline EG203/Tengeru97 & $100.0 \pm 0.0 \mathrm{a}$ & $98.4 \pm 2.2 a b$ \\
\hline EG219/Tanya & $100.0 \pm 0.0 \mathrm{a}$ & $99.0 \pm 1.6 a b$ \\
\hline EG219/Cal-J & $100.0 \pm 0.0 \mathrm{a}$ & $100.0 \pm 0.0 a$ \\
\hline EG219 Riogrande & $100.0 \pm 0.0 a$ & $97.9 \pm 1.8 a b$ \\
\hline EG219/Tengeru97 & $100.0 \pm 0.0 \mathrm{a}$ & $100.0 \pm 0.0 \mathrm{a}$ \\
\hline Hawaii 7996/Tanya & $97.9 \pm 3.6 \mathrm{a}$ & $78.6 \pm 4.8 \mathrm{~b}$ \\
\hline Hawaii 7996/Cal-J & $98.9 \pm 1.8 a$ & $81.2 \pm 6.9 b$ \\
\hline Hawaii 7996/Riogrande & $100.0 \pm 0.0 \mathrm{a}$ & $80.2 \pm 2.5 b$ \\
\hline Hawaii 7996/Tengeru97 & $100.0 \pm 0.0 \mathrm{a}$ & $78.2 \pm 1.2 b$ \\
\hline F-test & 6.57 & 2.36 \\
\hline$P$ value & 0.001 & 0.017 \\
\hline
\end{tabular}

$a, b$ : Numbers bearing the same letters within the column are insignificantly $(P<0.05)$ different according to StudentNewman Keuls.

Results show that grafted local tomato cultivars on eggplant rootstocks had significantly $(P \leq 5 \%)$ higher survival level in the open hardening nursery than that of local tomato cultivars grafted on tomato rootstock Hawaii 7996. The graft survival level in the open hardening nursery of local tomato cultivars grafted on eggplant rootstocks ranged from $86.4 \%$ for EG203/Cal-J to $100 \%$ for EG219/Cal-J (Table 2). Conversely, the survival level in the open hardening nursery of local tomato cultivars grafted on rootstock Hawaii 7996 ranged from $30.9 \%$ for

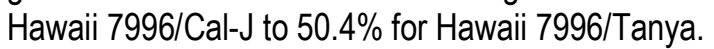


Table 2: Effect to rootstock on survival of grafted Tanzanian local tomato cultivars during hardening stage

\begin{tabular}{l|c}
\hline Rootstock-scion combination & Survival at hardening (\%) stage \\
\hline EG203/Tanya & $93.2 \pm 4.9 \mathrm{a}$ \\
EG190/Tanya & $96.9 \pm 5.4 \mathrm{a}$ \\
EG190/Cal-J & $96.9 \pm 5.4 \mathrm{a}$ \\
EG190/Riogrande & $93.7 \pm 2.5 \mathrm{a}$ \\
EG190/Tengeru97 & $92.5 \pm 7.7 \mathrm{a}$ \\
EG195/Tanya & $92.3 \pm 10.9 \mathrm{a}$ \\
EG195/Cal-J & $92.4 \pm 4.9 \mathrm{a}$ \\
EG195/Riogrande & $94.8 \pm 5.4 \mathrm{a}$ \\
EG195/Tengeru97 & $94.8 \pm 3.6 \mathrm{a}$ \\
EG203/Cal-J & $86.4 \pm 19.3 \mathrm{a}$ \\
EG203/Riogrande & $96.5 \pm 0.3 \mathrm{a}$ \\
EG203/Tengeru97 & $93.7 \pm 8.8 \mathrm{a}$ \\
EG219/Tanya & $99.0 \pm 1.6 \mathrm{a}$ \\
EG219/Cal-J & $100.0 \pm 0.0 \mathrm{a}$ \\
EG219 Riogrande & $93.5 \pm 8.5 \mathrm{a}$ \\
EG219/Tengeru97 & $89.7 \pm 6.7 \mathrm{a}$ \\
Hawaii 7996/Tanya & $50.4 \pm 6.2 \mathrm{~b}$ \\
Hawaii 7996/Cal-J & $30.9 \pm 4.9 \mathrm{~b}$ \\
Hawaii 7996/Riogrande & $31.6 \pm 7.8 \mathrm{~b}$ \\
Hawaii 7996/Tengeru97 & $45.1 \pm 1.1 \mathrm{~b}$ \\
\hline F-test & 2.95 \\
P-value & 0.003 \\
\hline a: N &
\end{tabular}

$a, b$ : Numbers bearing the same letters within the column are insignificantly $(P<0.05)$ different according to StudentNewman Keuls.

The high graft success between eggplant rootstocks and local tomato cultivars of 90 - $100 \%$ reported in this study is comparable to the worldwide commercial vegetable graft success of $85-90 \%$ using tube method (Oda, 1995). Formation of abundance trans-union xylem or big root systems is reported to account for the high graft success in vegetables (Parkinson et al., 1987; MartinezBallesata et al., 2010). However, the relatively low graft success of $30.9-50.4 \%$ between rootstock Hawaii 7996 and local tomato cultivars at the hardening nursery stage contradicts with previous reports. According to Oda et al. (2005) incompatibility between the scion and rootstock increases as the result of poor formation of trans-union xylem across the graft union. The formation of this trans- union xylem in grafted tomato begins between the fourth and eighth day and is fully completed at 15th day from the date of grafting (Fernandez-Garcia et al., 2004). The low survival level of local tomato cultivars when grafted on rootstock Hawaii 7996 was possibly due to higher seedling growth rate of the later compared to local tomato cultivars. For example, in a separate study, seedling height increment of rootstock Hawaii 7996 was $17.40 \mathrm{~cm}$ per month compared to $8.43 \mathrm{~cm}$ per month of eggplant rootstock and $10.25 \mathrm{~cm}$ per month of tomato $\mathrm{cv}$. Tengeru 97 seedling. The difference in rootstock and scion seedling growth rates has been associated with partial graft incompatibility (Martinez-Ballesata et al., 2010). 


\section{Msogoya and Mamiro J. Appl. Biosci. $2016 \quad$ Grafting compatibility between selected rootstocks and Tanzanian local tomato cultivars}

\section{CONCLUSION}

Eggplant rootstocks EG190, EG195, EG203 and EG219 can be grafted on Tanzanian local tomato cultivars with high graft success of $90-100 \%$. This high graft success is achieved when temperature and relative humidity in the dark and transparent chambers are maintained at 85 -
$95 \%$ and of $21-32^{\circ} \mathrm{C}$, respectively coupled with misting of the grafted seedlings as wilting signs appear. Further studies are required to optimize the healing conditions for improving graft success of local tomato cultivars on rootstock Hawaii 7996.

\section{ACKNOWLEDGMENT}

The authors gratefully acknowledge the financial support of USAID Innovative Agricultural Research Initiatives (iAGRI) and AVRDC in Taiwan for provision of rootstock seeds.

\section{REFERENCES}

Fernandez-Garcia, N., Carvajal, M. and Olmos, E. 2004. Graft Union Formation in Tomato Plants: Peroxidase and Catalase Involvement. Annals of Botany 93: 53 - 60.

Martinez-Ballesata, M.C, Alcaraz-Lopez, C., Muries, B. (2010). Physiological aspects of rootstock-scion interactions. Scientia Horticulturae 127: 112 118.

Oda, M. (1995). New grafting methods for fruit-bearing vegetables in Japan. Japan Agricultural Research Quarter. 29: 187 - 194.

Oda, M., Maruyama, M. and Mori, G. (2005). Water onto Solanum rootstocks. Journal of Japanese Society of Horticultural Science 74: 458 - 463.

Parkinson, M., Jefferee, C.E. and Yeoman, M.M. (1987). Incompatibility in cultured explant-grafts between members of the Salanaceae. New Phyto. 107: 489 - 498.

Rivard, C.L. and F.J. Louws, 2006. Grafting An Integrated Approach for Soil borne Disease Management. Proceedings from the 21st, Annual Tomato Disease Workshop. Fletcher, NC USA. transfer at graft union of tomato plants grafted 